\title{
ACCELERATION OF VILLAGE WELFARE THROUGH BUMDES: DISORIENTATION OF IMPLEMENTATION OF BUMDES REGULATIONS AND POLICIES
}

\author{
*Rianda Dirkareshza, **Eka N.A.M Sihombing \\ *Fakultas Hukum, Universitas Pembangunan Nasional Veteran Jakarta, Jakarta; \\ **Fakultas Hukum, Universitas Muhammadiyah Sumatera Utara, Medan. \\ Corresponding author. Email: riandadirkareshza@upnvj.ac.id \\ Received on: 11-08-2021; Revised on: 27-10-2021; Approved to be published on: 08-11-2021; \\ DOI:http://dx.doi.org/10.30641/dejure.2021.V21.419-434
}

\begin{abstract}
Village-Owned Enterprises (BUMDes) do not have legal certainty regarding their form of legal entity and it will make it difficult to meet the hope of all villagers to run businesses together in accordance with their characteristics, potential, and their respective resources. This research aims to provide input and solutions to the government to be able to accelerate the welfare of villages through BUMDes. The method used in this research is literary or library research by using normative juridical approach. In the processing of data, this journal used qualitative and quantitative approach. This research showed the result that there is disorientation in the implementation of BUMDes regulations and policies, such as: first, the incompatibility of village regulations with other laws and regulations. Second, the low community initiative in driving the village economy. Third, the vagueness of BUMDes position as a social and commercial institution. Fourth, policies that have not directed the professionalism of BUMDes. The solution in accelerating village welfare through BUMDes is to provide the flexibility of BUMDes in the form of legal entity as a bridge to be able to enlarge capital in the investment sector.
\end{abstract}

Keywords: village-owned, enterprises; village welfare, legal entities

\section{INTRODUCTION}

In Law No. 32 Year 2004 concerning Regional Government and Government Regulation No. 72 Year 2005 concerning Villages, it is mandated that in increasing community and village income, the village government can establish Village-Owned Enterprises (BUMDes) in accordance with the needs and potential of the village. In terms of planning and formation, BUMDes is established on the initiative of the community, and is based on cooperative and emancipatory principles. ${ }^{1}$ Bearing in mind that the professionalism of BUMDes management must really be based on community agreement, the production and consumption interests must be carried out professionally.

The development process which is carried out in the lowest government areas is in villages and urban villages. Building villages and managing cities are the government's hope for community

Riris Eka Widayanti and Renny Oktafia, "Strategi Pemasaran Berbasis Online Pada Produk Badan Usaha Milik Desa (Bumdes) 'Sukses Bersama' Desa Sugihwaras Kabupaten Sidoarjo," Jurnal Tabarru': Islamic Banking and Finance 4, no. 1 (2021): 245. participation in development in villages or urban villages, either by implementing it directly in the form of self-help or mutual assistance. The main goal of village development is to make villages throughout Indonesia have a level of community development, have a standard of living and welfare that continues to increase. ${ }^{2}$ The economic assets in a village must be fully managed by the village community. The institutional form as mentioned above is called BUMDes (Village-Owned Enterprise). BUMDes is a pillar of economic activity in a village that functions as a social and commercial institution. ${ }^{3}$

Village development that is completely delegated to villages can only be achieved if the

\footnotetext{
Hyronimus Se and Lambertus Langga, "PERANAN BUMDes DALAM MENDUKUNG PEREKONOMIAN DAN MENINGKATKAN KESEJATERAAN MASYARAKAT DESA WATUSIPI KECAMATAN ENDE KABUPATEN ENDE," Resona Jurnal Ilmiah Pengabdian Masyarakat 5, no. 1 (2021): 76.

3 Nur Laili Yuliani et al., "Pengembangan Dan Pemberdayaan BUMDes Di Dusun Bebengan, Salaman, Magelang Guna Meningkatkan Perekonomian Masyarakat," Community Empowerment 6, no. 3 (2021):343
} 
village government helps empower the village community to work hand in hand in accordance with the village identity, so that the village becomes strong, independent, and can organize village government, create development in each region, and create a prosperous community. ${ }^{4}$

The management of BUMDes is fully implemented by the village community, namely from the village, by the village, and for the village. ${ }^{5}$ Through village deliberations, the establishment of BUMDes is agreed upon and managed in a spirit of kinship and cooperation. ${ }^{6}$ There are not many theories that specifically discuss VillageOwned Enterprises (BUM Desa), because BUM Desa is a new instrument of Government policy as an effort to develop the economic base in villages. Even though it is more than 15 (fifteen) years old, referring to its birth in 2004 through Article 213 of Law Number 32 Year 2004 concerning Regional Government, BUMDes still does not have a specific form that is able to explain its difference from business entities and/or existing business entities in accordance with the laws and regulations.

The basic arrangement for BUMDes initially only made BUMDes a business entity that was directly owned by a village which functioned to create added value for the potential of the village and could also function in order to fulfil or meet the needs of the majority of the village community.

The elaboration of Central Government policies through Government Regulation Number 72 Year 2005 concerning Villages seems to delegate the issue of BUMDes growth and development to the regions. However, the provisions in Articles
78 to 81 of Government Regulation No. 72/2005 are sufficient to mark BUMDes as the basis for economic development in villages. In this early stage, the arrangement is still quite minimalist and simple, so that it is not possible to have institutional governance arrangement, let alone thinking about the expansion and development of BUM Desa businesses. It can be said that BUMDes at this stage is still in the incubation policy process. This can be seen in the series of regulations of Government Regulation No. 72/2005 which tend to delegate BUM Desa issues directly to regencies/ municipalities.

At least the delegation regulated by the Regency/Municipal Regulation in Article 81 paragraph (2) of Government Regulation No. 72/2005 consists of:

1. "Form of legal entity;

2. Management;

3. Rights and obligations;

4. Capital;

5. Profit sharing;

6. Cooperation with third parties; and

7. Mechanism of management and accountability"

The issue of the form of legal entity of BUMDes has the potential to become a latent problem that is raised along with the enactment of Law No. 6 Year 2014 concerning Villages (Village Law). BUMDes functions to build a pillar of economic activity in a village and functions as a social and commercial institution. ${ }^{7}$

\footnotetext{
4 Endra Wijaya and Mochamad Firmansyah Roni, "Praktik Pengelolaan Keuangan Desa Dan FaktorFaktor Yang Memengaruhinya," Jurnal Ilmiah Kebijakan Hukum 13, no. 2 (2019): 165.

5 Ade Onny Siagian, "Analisis Pengembangan Badan Usaha Milik Desa (Bumdes) Harapan Oesena Di Desa Oesena Kecamatan Amarasi Kabupaten Kupang," Jurnal Riset Entrepreneurship 4, no. 1 (2021): 34.

6 Muhammad Ridwan Basalamah, "Optimisation of Management of BUMDes : The Case in East Java Province" 4, no. 2 (2021): 14.
}

\footnotetext{
7 Departemen Pendidikan Nasional Pusat Kajian Dinamika Sistem Pembangunan (PKDSP) Fakultas Ekonomi, Buku Panduan Pendirian Dan Pengelolaan Badan Usaha Milik Desa (Malang: Universitas Brawijaya, 2007), 3 .
} 

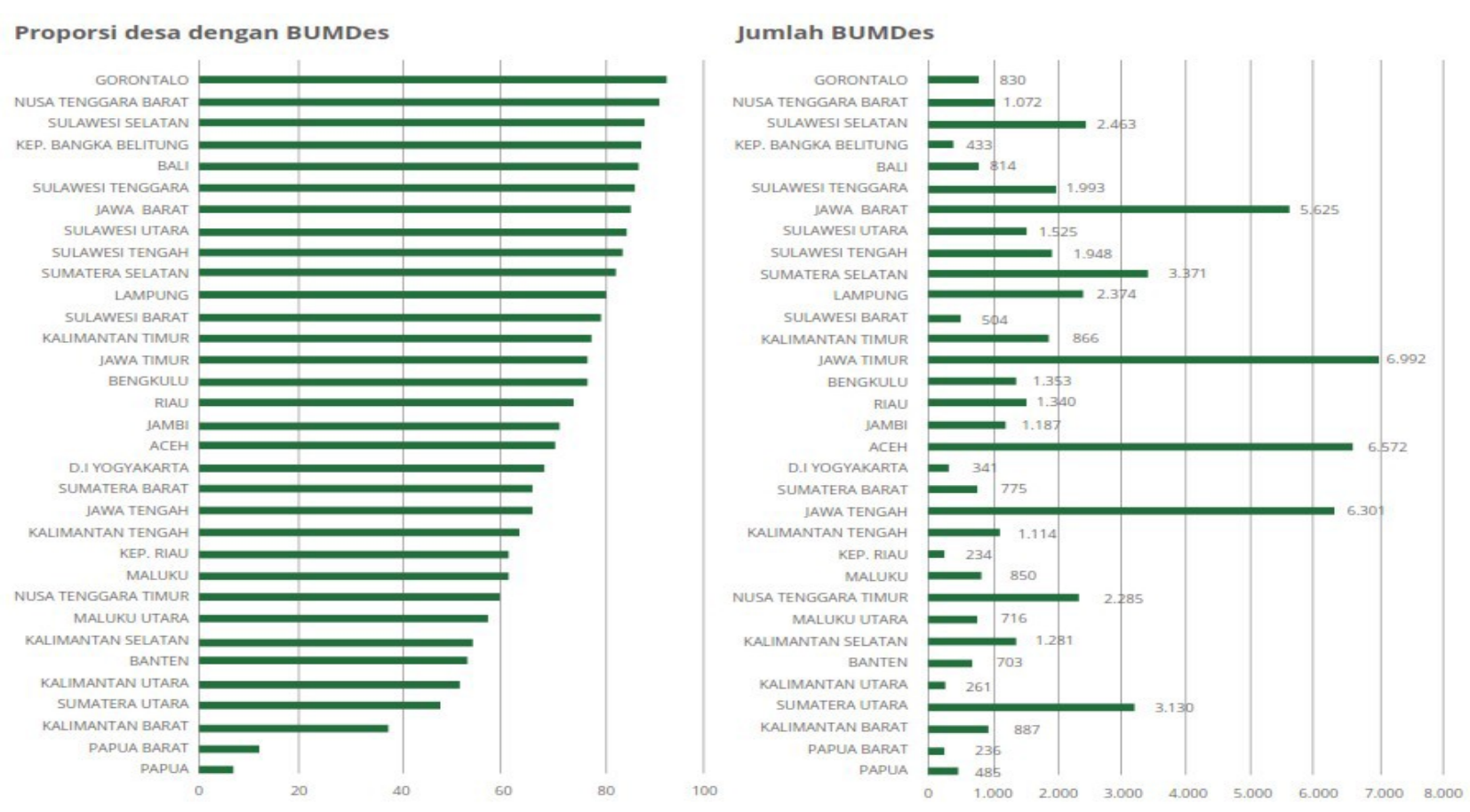

Figure 1. Distribution of Village-O wned Enterprises (2019)

Source: TNP2K ${ }^{8}$

In the same reasoning regarding the similarities in the definition of State-Owned Enterprises (BUMN) and BUMDes, Regional Research and Information Center. ${ }^{9}$ From the comparison of BUMDes in Law No. 32 Year 2004 and Law No. 23 Year 2014, BUMDes according to Law No. 32 Year 2004 is more aimed at community empowerment and the formation of BUMDes is more aspirational. Furthermore, in Law No. 23 Year 2014 BUMDes has been related since the enactment of Law No. 6 Year 2014, therefore there is a discourse regarding the form of legal entity of BUMDes. Similar businesses are owned by village communities so that the government's role is needed to support the distribution of the profits of village community's business in order to achieve village community welfare. Furthermore, BUMDes and village funds still have problems, because there is no minimum benchmark of at least $10 \%$ of village funds for BUMDes.

8 Priadi Asmanto et al., "Pendayagunaan Badan Usaha Milik Desa Dalam Pemulihan Ekonomi Pascawabah Covid-19," SEKRETARIAT TIM NASIONAL PERCEPATAN PENANGGULANGAN KEMISKINAN (Jakarta: SEKRETARIAT TIM NASIONAL PERCEPATAN PENANGGULANGAN KEMISKINAN, 2020), 2.

9 Muhammad Yasin et al., Anotasi Undang-Undang No.6 Tahun 2014 Tentang Desa (Jakarta: Pusat Telaah dan Informasi Regional (PATTIRO), 2014), 401-402.
BUMDes has no legal certainty regarding its form of legal entity and it will make it difficult to meet the expectations of all villagers to run business together in accordance with their respective characteristics, potentials, and resources. Because the forms of business that exist in a village are not as fragmented as life in the cities; the forms of business in a village tend to be homogeneous or have the same characteristics.

The data that can be a concern for the BUM Desa business is that the village economy in Indonesia has a household base. According to the data in 2015-2016, there was a decrease in the area of agricultural land from 25,144,961 Ha to 24,806,582 $\mathrm{Ha}^{.{ }^{10}}$ Between 2008-2018, there was a decrease in the percentage of villages based on agricultural typology from $88.20 \%$ to $86.98 \%$. Another version of data shows the number of villages and urban villages of 83,184 (74,754 villages $+8,430$ urban villages) or about $73.14 \%$ are in the context of the Agricultural Typology Village. Completely for comparison, namely Typology of Agriculture - Rice Fields, Plantations, Cultivation (73.14 percent); Coastal (15.11 percent); Forestry (3.4 percent); Livestock

1o Fajar Sidik, "Implementasi Kebijakan Badan Usaha Milik Desa (Bumdes): Unit Usaha, Pendapatan Dan Inefisiensi," Jurnal Ekologi Birokrasi 5, no. 3 (2017): 37. 
(0.29 percent); Mining (0.45 percent); and Trade/ Services (9.75 percent). ${ }^{11}$

The condition of this data is not able to make villages to reach the stage of food security, even villages have slowly but surely experienced a significant decrease in land. In the period of a year between 2015-2016, the reduced village land reached 338,379 $\mathrm{Ha}$, and it directly impacted the production and income of farmers. In a larger context, efforts to empower village communities through BUMDes seem to encounter problems with the poverty percentage data between urban areas which moves in the range of $8-14 \%$; and data on the percentage of poverty in village areas that move almost doubled urban areas which reached $14-20 \%$. This means that the poverty rate in village areas has not moved in line with the trend of the rampant establishment of BUMDes which reaches $61 \%$ of the number of villages in Indonesia (45,549 BUMDes units).

Research on village welfare through BUMDes was conducted by Maria Rosa Ratna Sri Anggraeni and it can be found in a journal published in 2021. The journal states that the existence of BUMDes brings changes in the economic and social fields. The existence of BUMDes does not bring significant benefits to improving the welfare of community directly. The problems that arise related to BUMDes are community access to water and community access to get jobs in BUMDes. ${ }^{12}$

Similar research was also conducted by Agus Surono. His article focuses on the role of law in village-scale management by BUMDes, where the focus of the purpose of the article is the same as the author's paper that is to improve the welfare of village communities. The results of this research are the arrangements in various laws and regulations related to village-scale natural resource management by BUMDesa and the concept of village-scale natural resource management has been in line and in accordance with the fifth principle of Pancasila, namely "social justice for all Indonesian people”, but it still needs

" Badan Pusat Statistik, Village Potential Statistics of Indonesia 2018 (Jakarta: Badan Pusat Statistik, 2018), 101.

12 Maria Rosa Ratna Sri Anggraeni, "Peranan Badan Usaha Milik Desa (Bumdes) Pada Kesejahteraan Masyarakat Pedesaan Studi Pada Bumdes Di Gunung Kidul, Yogyakarta," Modus 28, no. 2 (2016): 155. to be supervised by related parties according to the authority of both the Central Government and the Regional Government, so that the fulfillment of village rights to village-scale natural resources can actually be realized. Therefore, it is necessary to regulate technical provisions for monitoring and evaluation as well as providing guidance to villages. ${ }^{13}$

In a thesis compiled by Garnies Lellyana Sagita with the title "The Role of Village-Owned Enterprises (BUMDes) in Improving the Welfare of Village Communities Based on Law No. 6 Year 2014 concerning Villages (Case Study of BUMDes Tirta Mandiri Klaten)" in 2017, it is explained that the management of BUMDes aims to improve the economic welfare of villagers through the development of their economic businesses. The establishment of BUMDes is intended to encourage/accommodate all activities to increase community income, both those that develop according to local customs/culture. Management of business units under BUMDes is a more appropriate management than management under cooperatives. ${ }^{14}$

This research complements previous research that discuss village welfare through BUMDes located throughout Indonesia. In the first research, it was stated that BUMDes did not bring significant benefits to improving the welfare of residents directly. The second research stated that it is necessary to carry out supervision by related parties according to the authority of both the Central Government and the Regional Government, stating that the fulfillment of village rights to village-scale natural resources can actually be realized. The third research stated that the management of business units under BUMDes is a more appropriate management than the management under cooperatives. Based on the three previous research that have been described, there are similarity and difference. The similarity

13 Agus Surono, "Peranan Hukum Dalam Pengelolaan Sumber Daya Alam Skala Desa Oleh Badan Usaha Milik Desa (BUMDes) Dalam Meningkatkan Kesejahteraan Masyarakat Desa," Jurnal Rechts Vinding: Media Pembinaan Hukum Nasional 6, no. 3 (2017): 459.

14 Garnies Lellyana Sagita, "Peran Badan Usaha Milik Desa (BUMDes) Dalam Meningkatkan Kesejahteraan Masyarakat Desa Berdasarkan UU No. 6 Tahun 2014 Tentang Desa (Studi Kasus BUMDes Tirta Mandiri Klaten)," Universitas Muhammadiyah Surakarta (Universitas Muhammadiyah Surakarta, 2017), 1. 
is that they have the same goal, namely to improve village welfare through BUMDes. While the difference is in the problem of disorientation in the implementation of BUMDes regulations and policies, where the author assumes that there are several factors that cause the less optimal management of BUMDes due to overlapping rules and disorientation in their implementation.

In connection with this, with the data presented, it can be seen that BUMDes has the potential to be used as a motor in the acceleration of the village economy itself, even if it can be managed optimally, BUMDes can help the nation's economy. Therefore, the author is interested in writing this article in order to provide input on the management of BUMDes from a legal point of view, especially in the field of business law.

Based on the description above, the statement of the problem of this research focuses on, among others: first, how is the disorientation of the implementation of BUMDes regulations and policies? Second, how do we accelerate village welfare through BUMDes optimally?

\section{RESEARCHMETHOD}

The type of research in this journal is literary or library research, meaning a study by examining books related to this journal from the library (library materials). All sources come from written (printed) materials related to the research problems and other literature (electronic). ${ }^{15}$ In data processing, this journal used a qualitative and quantitative approach. In the discussion, the researchers used a juridical-normative approach, which is a type of approach using the provisions of the legislation which applies in a country or a doctrinal legal approach method, namely legal theories and opinions of legal experts, especially those related to the issues discussed. ${ }^{16}$ The juridical-normative approach used in this research is an approach through positive law, which examines positive legal rules to find what are the obstacles that lead to disorientation in the implementation of regulations and policies in the management of BUMDes and find a way out to be able to accelerate village welfare through BUMDes in an optimal manner.

15 Sutrisno Hadi, Metodologi Riserch 1 (Yogyakarta: Gajah Mada, 1980), 35.

16 Ronny Hanitijo Soemitro, Metode Penelitian Hukum (Jakarta: Ghalia Indonesia, 1985), 24.

\section{DISCUSSION AND ANALYSIS}

Basically, the implementation of the BUMDes arrangement in the Village Law has several obstacles and problems that occur in regions. Problems that occur in practice are said to be diverse, occurring on stakeholders, both the Provincial Government and Regency Government as regulators and BUM Desa administrators as executives. ${ }^{17}$ The implementation of the Village Law for BUMDes itself is expected to cause an increase in village welfare, because BUMDes is a business entity whose entire or most of the capital is owned by a village through direct participation from village assets which are separated to manage assets, services, and other businesses for maximum welfare of the village community. ${ }^{18}$

In reality, village development through BUMDes is still lacking, so there are still many villages that are left behind. ${ }^{19}$ However, there have been many ways that have been taken by the government to alleviate the problem of underdeveloped villages, such as increasing the budget for village development from year to year in order to be able to reduce the number of villages that are left behind and several other programs. ${ }^{20}$ Based on these assumptions, the existence of BUMDes should get serious attention from the central government with the birth of policies related to community empowerment which are carried out by collecting and institutionalizing community economic activities.

One of the hopes of establishing BUMDes in a village is as a tool to increase village independence, especially in the economic field. ${ }^{21}$ It is intended that the profits from the business carried out by BUMDes will go into the village

${ }_{17}$ Suparji, Pedoman Tata Kelola BUMDes (Jakarta: UAI Press, 2019), 21.

18 Admin Dispmd, "Memahami Dan Mengerti : Badan Usaha Milik Desa (BUMDes)," Dispmd.Bulelengkab. Go.Id. diakses pada tanggal o2 Mei 2021.

19 Edy Yusuf Agunggunanto et al., "PENGEMBANGAN DESA MANDIRI MELALUI PENGELOLAAN BADAN USAHA MILIK DESA ( BUMDes ) Fitrie Arianti Universitas Diponegoro Semarang," Jurnal Dinamika Ekonomi dan Bisnis 13, no. 1 (2016): 70.

2o Humas KEMENKO PMK, "2020, Dana Desa Fokus Pada Pemberdayaan Masayarakat Dan Pengembangan Potensi Ekonomi Desa," Www.Kemenkopmk.Go.Id. diakses pada tanggal o5 Mei 2021.

${ }_{21}$ Badan Pusat Statistik, Statistik Infrasruktur Indonesia 2020 (Hasil Pemutakhiran Data Perkembangan Desa 2020) (Jakarta: Badan Pengkajian MPR RI, 2020), 57. 
treasury fund as Village Original Income (PADes). However, this has not been running optimally with several factors causing disorientation in the implementation of regulations and policies provided by the government.

\section{A. Disorientation of the Implementation of BUMDes Regulations and Policies.}

Villages, or those which are called by other names, existed before the Unitary State of the Republic of Indonesia in terms of the composition and administration of Regional Government, after the amendment to the 1945 Constitution of the Republic of Indonesia. ${ }^{22}$ Jimly Asshiddiqie in Oki states that the mention of rights in the 1945 Constitution of the Republic of Indonesia brought certain consequences, both to the qualification and which party had the main obligation to fulfill it. It is necessary to expand the reach of dissemination to the village/urban village level. ${ }^{23}$

The establishment of a Legal Aware Village/ Urban Village begins with the stipulation of a village/urban village that already has a Kadarkum (Legal Aware Family) Group to become a Fostered Village/Urban Village (DB). Element of Legal Culture, in the form of socio-cultural values that apply in society, forms a mindset and influences the good behavior of community. ${ }^{24}$ For this reason, if the government will regulate society nationally, only the principles should be regulated, not the norms, so that the norms that they have adhered to so far can survive. ${ }^{25}$ Because it is a form of public interest, the purpose of establishing public

${ }^{22}$ Muhaimin Muhaimin, "Rekonstruksi Penggunaan Dana Desa Untuk Mewujudkan Kesejahteraan Masyarakat Desa," Jurnal Penelitian Hukum De Jure 20, no. 4 (2020): 557

${ }^{23}$ Oki Wahju Budijanto, "Peningkatan Akses Bantuan Hukum Kepada Masyarakat Miskin," Jurnal Penelitian Hukum De Jure 16, no. 4 (2017): 463-475, https:// ejournal.balitbangham.go.id/index.php/dejure/ article/viewFile/193/56.

24 Oksimana Darmawan; Okky Chahyo Nugroho, "IMPLEMENTASI KEBIJAKAN PENGUSULAN DESA/KELURAHAN BINAAN MENJADI DESA/KELURAHAN SADAR HUKUM (Policy Implementation Proposing Construction Village to Become Village Aware of Law)," Jurnal Penelitian Hukum De Jure 20, no. 2 (2020).

25 Ahyar Ari Gayo, "Perlindungan Hukum Hak Atas Tanah Adat (Studi Kasus Di Provinsi Aceh Khususnya Kabupaten Bener Meriah) (Legal Protection For Title Over Customary Land (Case Study In The Province Of Aceh In Particular, The Regency Of Bener Meriah))," De Jure jurnal penelitian hukum 18, no. 3 (2018): 15. facilities is of course the same as the purpose of establishing public interests, namely for the welfare and prosperity of the community. ${ }^{26}$

There is no legality aspect in the legal structure, i.e. there is no legal structure of the village/urban village team (stipulation of establishment, development of the fostered village/urban village to become legally aware village/urban village). ${ }^{27}$ The legal culture of the community through increasing the community's legal awareness is marked by the increasing number of villages/urban villages that are aware of the law through legal counseling activities, both directly and indirectly, supported by the participation of all government/private institutions and the public who are concerned with legal issues. ${ }^{28}$

1. Village Regulations which are not Integrated with Other Laws and Regulations

One of the important things that often arises is that there are many overlapping rules or the asynchrony of the regulations governing villages. ${ }^{29}$ Until now, it is still not clear what exactly the central institution that oversees the village government is. This is different from local governments where the supervisory agency is the Ministry of Home Affairs (Kemendagri). Even though villages already have their own autonomy in accordance with the Village Law. Therefore, it is felt that villages need to be harmonized again with Law Number 23 Year 2014 concerning Village Government (UU Pemdes). Because the Village Government Law was born later than the Village Law. In terms of mandate, in accordance with the Village Law, village management should be held by a Ministry that is specifically related

${ }^{26}$ Agus Surono, "Peranan Hukum Dalam Pengelolaan Sumber Daya Alam Skala Desa Oleh Badan Usaha Milik Desa (BUMDes) Dalam Meningkatkan Kesejahteraan Masyarakat Desa," Jurnal Rechts Vinding: Media Pembinaan Hukum Nasional 6, no. 3 (2017): 459.

${ }_{27}$ Oksimana Darmawan, "Implementasi Norma Standard Di Rumah Detensi Jakarta Dalam Upaya Pencegahan Konflik Antar Deteni," Jurnal Ilmiah Kebijakan Hukum 10, no. 1 (2016): 71-86.

28 Jawardi Jawardi, "STRATEGI PENGEMBANGAN BUDAYA HUKUM (Strategy of Law Culture Development)," Jurnal Penelitian Hukum De Jure 16, no. 1 (2016): 77.

29 Diani et.al Sadiawati, Kajian Reformasi Regulasi Di Indonesia: Pokok Permasalahan Dan Strategi Penanganannya, Kementerian PPN/Bappenas (Jakarta: Yayasan Studi Hukum dan Kebijakan Indonesia (YSHK), 2019), 34. 
to village affairs. However, the current facts require the existence of two Ministries, namely the Ministry of Home Affairs and the Ministry of Village, Development of Disadvantaged Regions, and Transmigration. Incoherence can occur if the village is not accommodated by one ministry, then there is the potential for a tug of war to take place between one ministry and another in managing regional government affairs.

2. Low Community Internal Initiatives in Driving the Village Economy

The Village Law constructs village as a hybrid organization between self-governing community and local self-government. ${ }^{30}$ Village is also not identical with village government and village head, but includes local government and at the same time contains the community, all of which form a legal entity. ${ }^{31}$ This construction also brings differences between aspects of the study of BUMDes and State/Regional Owned Enterprises (BUMN/BUMD) which are business entities that act as government intervention tools at the national or regional economic level. Initiatives in establishing village businesses should also be present simultaneously in the internal village (village government and community) in village deliberation so that their presence can explore the potential and answer the problems faced by the village. In an article that has been published, it was found that more formation initiatives emerged from outside the village. Although there are also initiatives that come from internal villages (village government and the community), such as in Bleberan Village, Gunung Kidul. This initiative exists because it is motivated by conditions and problems that exist in the village. ${ }^{32}$ It is important in the establishment of BUMDes to understand the potential and conditions of the village which then on a joint initiative (village officials and the community) establishing BUMDes. The

\footnotetext{
3o Anom Surya Putra, Badan Usaha Milik Desa Spirit Usaha Kolektif Desa (Jakarta: EMENTERIAN DESA, PEMBANGUNAN DAERAH TERTINGGAL, DAN TRANSMIGRASI REPUBLIK INDONESIA, 2015), 15.

${ }^{31}$ Okta Hendrik, "Peran Kepala Desa Dalam Penyelenggaraan Pembangunan Desa Tanjung Keranjang Kecamatan Malinau Kota Kabupaten Malinau," eJournal Ilmu Pemerintahan 2, no. 2 (2013): 464 .

32 N Ngadisah and A Alma'arif, "Peran Dan Fungsi Bumdes Dalam Pembangunan Perdesaan (Studi Pada Desa Bleberan Kecamatan Playen Diy)," Jurnal Manajemen Pembangunan 2, no. 1 (2019): 6.
}

implementation of village deliberation in the establishment of BUMDes is not limited to merely administrative fulfillment, but it is necessary to look at the production factors that will encourage economic growth. Exceeding the target of establishing BUMDes must be accompanied by the quality and optimization of the business undertaken.

\section{Unclear Position of BUMDes as Social and Commercial Institution}

The Village Law provides flexibility for the type of business to be managed. ${ }^{33}$ In carrying out its functions, BUMDes is not only a commercial institution, but also social institution that has the ultimate goal of being able to contribute to the welfare of the community, especially those in the village where the BUMDes was established. It is just that these two functions are not widely discussed in Government Regulations and Ministerial Regulations. An understanding of BUMDes that must generate profits will lead to the choice of types of businesses that can generate profits only.

This will be a trade-off for the involvement and participation of citizens in the management and benefits of the business chosen for BUMDes ${ }^{34}$. The government needs to clarify the function of BUMDes as a social and commercial institution. The clarity of the rules related to these two functions will strengthen BUMDes, especially in conducting business cooperation with other parties. In addition, this clarity will be able to eliminate confusion for BUMDes managers. If technical instructions can be issued regarding the direction and objectives of this BUMDes institution, it will move optimally without thinking about business risks whose technical arrangements are still unclear in terms of management and implementation.

4. Policies that have not directed the professionalism of BUMDes

The management structure of BUMDes has not been fully adjusted to the Regulation of the Minister of Village Number 4 Year 2014 concerning BUMDes. The results can be seen by the fact that

33 Palmira Bachtiar et al., Laporan Studi Kasus UndangUndang Desa: Menelusuri Manfaat Belanja Desa (Jakarta, 2019), 4.

34 Pusat Perancangan dan Kajian Hukum (Pusperjakum) DPD RI, "Ini Faktor Pendukung Dan Penghambat Berkembangnya BUMDes," Https://Www.Desapedia. $I d /$., diakses pada tanggal 1 Juni 2021 
there are still BUMDes operational managers held by the Village Government apparatus. In addition, the BUMDes supervisory element is not clarified in the aforesaid Ministerial Regulation, especially in Government Regulation Number 43 Year 2015 concerning the Implementing Regulations of the Village Law. This condition makes the process of BUMDes accountability "false". Article 31 of the Regulation of the Minister of Village states that one of the duties of BPD members is to be the supervisor of BUMDes which is part/organ of BUMDes. Therefore, it can be said that BPD members carry out supervision over themselves, even though the accountability process is through the village government. Clarity of supervision is needed to anticipate potential moral hazard (misappropriation/abuse) by BUMDes executives. This clarity will realize the management of BUMDes which is democratic and in accordance with the principle of mutual cooperation. Therefore, BUMDes directors should pay attention to and apply professional management standards and uphold the principles of transparency and accountability.

The definition of Village Fund can be found in Article 1 number 8 of Government Regulation Number 43 Year 2014 as amended by Government Regulation Number 47 Year 2015 concerning Implementing Regulations of the Village Law. In this provision, the elements of the definition of the Village Fund are as follows:
a. "Sourced from the State Budget;
b. Funds intended for villages;
c. Transferred through the city/district budget; and

d. It is used to finance government administration, development implementation, community development, and community empowerment."

BUMDes as a means of village economic development, ${ }^{35}$ as well as community empowerment, is a priority in the allocation of Village Funds which is further regulated in a Government Regulation every year which is transferred through the District/City Budget. As was the case in 2019, through the Regulation

\footnotetext{
35 Muhammad Adib Junaidi, "Peran Badan Usaha Milik Desa (BUMDes) Dalam Penguatan Ekonomi Di Desa Kedung Turi Kecamatan Taman Kabupaten Sidoarjo," UNAIR Article 1, no. 1 (2018): 4.
}

of the Minister of Village, Development of Disadvantaged Regions and Transmigration Number 11 Year 2019 as amended by Regulation of the Minister of Village, Development of Disadvantaged Regions and Transmigration Number 6 Year 2020 concerning Priorities for the Use of Village Funds in 2020, one of the priorities for using Village Funds is for establishment, equity participation, capital strengthening, and other BUMDes and/or Joint BUMDes development activities in accordance with the authority of the village which is decided in village deliberation.

The existence of the Village Funds is a hope for advancing villages. At least, the revenue obtained by the State from the community returns to the community. ${ }^{36}$ The Village Fund is the prima donna among the Village income components. ${ }^{37}$ There is no clear provision regarding the amount or percentage of Village Fund which is intended for the establishment and development of BUMDes and/or Joint BUMDes. Therefore, there is no guarantee related to the minimum amount of Village Fund allocation for the establishment and development of BUMDes and/or Joint BUMDes, although the amount of the allocation is agreed upon in village deliberation.

The Village Fund in 2021 will still be given to villages. ${ }^{38}$ In the 2021 State Budget, the allocation of village funds reaches IDR 72,000,000,000,000 (seventy-two billion rupiah). The Regulation of the Minister of Village prioritizes the allocation of Village Funds to be directed to programs and/ or activities to accelerate the achievement of the SDGs, one of which is national economic recovery. Furthermore, the provisions for the use of Village Funds are intended for national economic recovery in accordance with the authority of villages as referred to in Article 5 paragraph (2) letter a, that the use of village funds is prioritized for the achievement of villages' SDGs, as follows:

\footnotetext{
${ }^{36}$ Jamal Wiwoho, "Peran Lembaga Keuangan Bank Dan Lembaga Keuangan Bukan Bank Dalam Memberikan Distribusi Keadilan Bagi Masyarakat," MasalahMasalah Hukum 43, no. 1 (2014): 89.

37 Beni Haryanto Marbun, Marlon Sihombing, and R. Hamdani Harahap, "Peranan Dana Desa Dalam Pengembangan Indeks Desa Membangun Di Kecamatan Sibolangit Kabupaten Deli Serdang Provinsi Sumatera Utara," Perspektif 9, no. 2 (2020): 440.

38 Direktur Pelaksanaan Anggaran - Ditjen Perbendaharaan, "Pedoman Penyaluran Dana Desa Ta 2021" (Jakarta: Kementerian Keuangan, 2021), 5.
} 
a. "establishment, development, and revitalization of village-owned enterprises/ joint village-owned enterprises for equitable village economic growth;

b. provision of village electricity to realize a clean and renewable energy village; and

c. productive economic business development which is prioritized to be managed by villageowned enterprises/joint village-owned enterprises to realize environmentallyconscious village consumption and production".

BUMDes funds sourced from the Village Fund in principle have become a priority, but the amount is not determined. Therefore, it is necessary to explicitly specify at least $10 \%$ of the Village Fund received by each village. Therefore, villages are encouraged to manage village potentials through village economic entity, namely BUMDes.

\section{B. Village Welfare Acceleration Through BUMDes}

BUMDes is proven to encourage village entrepreneurshipwiththedimensionsofexploration and empowerment, increasing capacity as well as support and involvement of all stakeholders. BUMDes was established in accordance with government policies based on village deliberation process as a culture of the Indonesian people by involving elements of the village government, associations and the community. ${ }^{39}$ However, in practice there are still many things that need to be addressed regarding the management of BUMDes business as described by the authors in the previous discussion. In this regard, before explaining how to accelerate village welfare through BUMDes, we can look at the attached figure regarding the potential of BUMDes in Indonesia.

39 Ikeu Kania, Grisna Anggadwita, and Dini Turipanam Alamanda, "A New Approach to Stimulate Rural Entrepreneurship through Village-Owned Enterprises in Indonesia," Journal of Enterprising Communities: People and Places in the Global Economy 15, no. 3 (January 2021): 432.

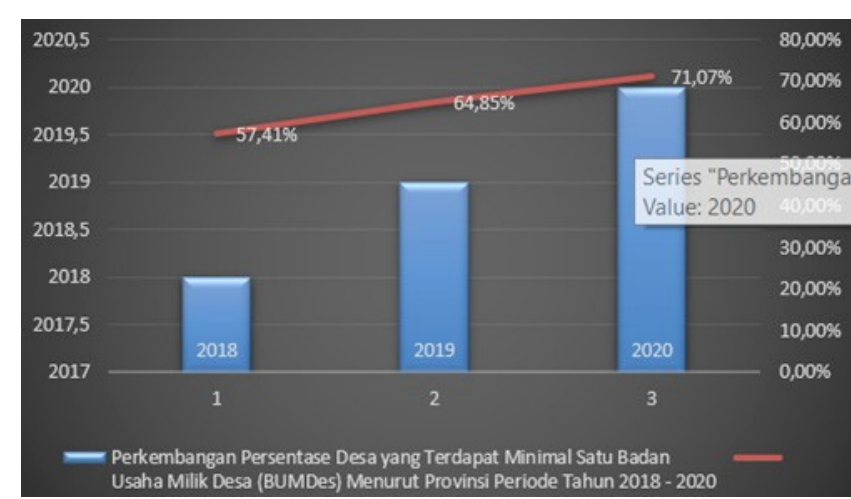

Figure 2. Development of Percentage of Villages That Have at least One Village-Owned Enterprise (BUMDes) by Province for the Period of 2018

- 2020. Source: Central Bureau of Statistic s, Ind onesia Infrastruc ture Statistic s in $2019^{40}$ and $2020^{41}$

If we look at the data presented in the figure, it can be seen that the establishment of BUMDes always develops every year and is almost evenly distributed in all provinces in Indonesia. However, this must be accompanied by good regulations to be able to support the management so that it can realize good PADes to be able to provide welfare to all villages. In this case the authors have an argument of accelerating village welfare through investment and restructuring sanctions and disharmony of laws and regulations in the management of BUMDes.

Investment is all forms of activity of investing, both by domestic investors and foreign investors to conduct business in the territory of the Republic of Indonesia ${ }^{42}$ The parties involved in the investment process include the Central Government, Regional Governments, the Investment Coordinating Board (BKPM) etc. Investment activities can be carried out by investors in several ways, including by subscribing shares at the time of the establishment of a limited liability company, purchasing shares, and doing other ways in accordance with the provisions of laws and regulations.

Law Number 25 Year 2007 concerning Investment classifies investment into several forms, namely:

40 Badan Pusat Statistik, Statistik Infrastruktur Indonesia 2019 Hasil Pemutakhiran Data Perkembangan Desa 2019 (Jakarta: Badan Pusat Statistik, 2019), 41,

${ }^{41}$ Badan Pusat Statistik, Statistik Infrasruktur Indonesia 2020 (Hasil Pemutakhiran Data Perkembangan Desa 2020).

42 Laurensius Arliman S, "Penanaman Modal Asing Di Sumatera Barat Tentang Penanaman Modal," Supremasi Jurnal Hukum 1, no. 1 (2018): 9. 
a. "Direct investment is an investment activity carried out directly in a country. The existence of direct investment by carrying out its activities by establishing its own company, as well as joint ventures with domestic companies, joint operation schemes, converting debt participation into shares in companies, as well as providing technical and managerial assistance.

b. Indirect investment is an investment activity carried out indirectly in a country. This indirect investment is carried out by purchasing securities in the capital market and money market by purchasing shares or bonds as well as foreign exchange with the principle of seeking profit and investors are not directly involved in their business management activities.

c. The sources of investment financing according to Law No. 25 Year 2007 concerning Investment can be categorized into 2 (two) groups, namely domestic investor and foreign investor, as follows:

d. Domestic investors are individuals who are Indonesian citizens, Indonesian business entities, the Republic of Indonesia, or regions that make investments in the territory of the Republic of Indonesia. There are several examples of domestic investors who carry out their activities, namely MSMEs, PT. Djarum, PT. Kereta Api Indonesia, and PT. Bank Pembangunan Daerah Jawa Tengah.

e. Foreign investors are individuals who are foreign citizens, foreign business entities, and/or foreign governments that make investments in the territory of the Republic of Indonesia. Examples of foreign investors who carry out their activities are PT. Unilever Tbk and PT. Petronas Niaga Indonesia.”43

Based on this provision, the opportunity is that in BUMDes it is possible to invest, but it must be determined that it is done by whom and in what form. This is considering that BUMDes is not a business entity in the form of a Limited Liability Company. However, BUMDes can be a forum for business entities in the form of legal entity, be it Limited Liability Company or cooperatives.

\footnotetext{
43 Agus Saiful Abib, Endah Pujiastuti, and Tri Mulyani, "Konsep Penanaman Modal Sebagai Upaya Mestimulasi Peningkatan Perekonomian Indonesia," Hukum dan Masyarakat Madani 7, no. 1 (2017): 22-24.
}

Departing from the analysis above, it is clear that it is necessary to establish a Draft Law on Village-Owned Enterprises as a bridge to be able to realize public welfare through the establishment of a joint business based on the principle of kinship. ${ }^{44}$ Therefore, Village-Owned Enterprises must be regulated in the Law as the constitution directs it to do so, to be able to carry out acceleration of village welfare itself by optimizing the management of BUMDes.

In terms of sanctions, arrangements related to sanctions against managers are needed if there are BUMDes managers who commit fraud or abuse of authority in the implementation which results in losses for the village. The increasing number of BUMDes is reminiscent of the amount of village funds which in the past four years the state has provided IDR 187 trillion. Even in 2018, village funds were budgeted at IDR 60 trillion. ${ }^{45}$ The large village funds are not only focused on economic programs, but also on infrastructure development, improving the quality of public services, including eradicating village children's growth disorders caused by stunting. At least, from the reference, there are four priority areas that must be carried out by villages in the village fund program, one of which is to establish a BUMDes. That is, BUMDes is intended as a business institution that will encourage the economic productivity of villagers. Using equity participation from the village, BUMDes has various options to be made as a business in accordance with the potential it has and the market opportunities being targeted. The types of businesses that BUMDes can run are: ${ }^{46}$
1. Serving;
2. Banking;
3. Renting;
4. Brokering;
5. Trading;
6. Holding; and
7. Contracting.
44 Rianda Dirkareshza, “Aspek Usaha Bersama Berdasarkan Asas Kekeluargaan Dalam Pembatalan UU No. 17 Tahun 2012 Terkait Putusan Mahkamah Konstitusi No. 28/PUU-XI/2013" (Universitas Sumatera Utara, 2016), 53.
45 Berdesa, "Informasi Lengkap Tentang BUMDes Yang Harus Anda Ketahui," Berdesa.Com. diakses pada tanggal o3 Juni 2021.
46 Ibid.


From the existence of BUMDes, it turns out that there are problems that become obstacles for BUMDes to grow according to their ideals and to face the challenges posed by economic growth, markets and community needs. Based on the secondary data, the problems faced by BUMDes were identified as follows:

1. most BUMDes have not operated optimally;

2. guidance is needed for the establishment and development of BUMDes;

3. conflicts of interest among the main actors, the Village Government which is less open and does not involve the community in determining policies.

4. accountability for the management of BUMDes funds: there are discrepancies between reports and the implementation of activities, disbursement of funds that are not supported by evidence, and report verification is not carried out every month, which indicates that accountability is still relatively not going well;

5. BUMDes Corporate Governance (CG) issues;

6. Small and Micro Enterprises have different characteristics from BUMDes;

7. The relationship between BUMDes and Cooperatives, related to the possibility of BUMDes establishing cooperatives in villages;

8. The role of the Village Head in the development of BUMDes;

9. The business climate is not yet conducive for BUMDes;

10. BUMDes still experience limited information and market access;

11. Low productivity (low technology) and limited capital; and

12. The low entrepreneurial spirit of the community.

There is aspiration of rejection of the discourse on BUMDes regulation in the Law, due to concern that a quo Law will overlap with the Village Law. However, this is not entirely true because based on the facts that develop in the community, it shows that the legal politics of Village-Owned Enterprises has not been directed properly and correctly. Especially with the issue that Village-Owned Enterprises are one of the priorities in village administration.

On the other hand, BUMDes also has its own mechanism that focuses on village deliberation as the fundamental foundation in the operation of BUMDes. This decision making is an example of an important issue in the potential for legal disharmony brought about through a quo Ministerial Regulation. In addition, when referring to the three laws and regulations related to BUMDes, among others, as regulated in:

1. Law No. 6 Year 2014 concerning Villages;

2. Government Regulation No. 43 Year 2014 concerning Implementing Regulations of Law No. 6 Year 2014 concerning Villages; and

3. Regulation of the Minister of Village, Development of Disadvantaged Regions, and Transmigration No. 4 Year 2015 concerning the Establishment, Management, and Dissolution of Village-Owned Enterprises.

The three laws and regulations have not provided a clear or firm legal policy regarding the desired level of BUMDes development as a form of national development. One example that can be given is a description of a fundamental forum in strategic decision making which is inversely proportional, where if the BUMDes has a business unit in the form of a limited liability company, the decision making of the business unit is based on the GMS (as a logical consequence of the provisions of Article 8 letter a of the Regulation of the Minister of Village, Development of Disadvantaged Regions and Transmigration No. 4/2015). Whereas village deliberation should be the foundation for the operation of BUMDes as referred to in the provisions of Article 87 paragraph (2) and Article 88 paragraph (1) of the Village Law.

In addition, the provisions of the existing laws and regulations have not provided a clear legal political level related to the mechanization of BUMDes. For example, in determining the bankruptcy/loss of BUMDes, Government Regulation No. 43/2014, especially in the provisions of Article 139, determines that "losses experienced by BUMDes are the responsibility of the BUMDes operational executives”. Meanwhile, in Article 27 paragraph (1) of the Regulation of the Minister of Village, Development of 
Disadvantaged Regions and Transmigration No. $4 / 2015$, it is determined that "losses suffered by BUMDes shall be borne by BUMDes". At the level of laws and regulations that are still rooted in the same law, namely the Village Law, the two laws and regulations result in disharmony in terms of determining the burden of losses. How is the implementation of the establishment of a business unit that is a legal entity and is subject to the legal regime that regulates it towards the operational level of BUMDes as mandated by the Village Law? Of course, the potential for legal disharmony will be even greater.

Issues related to the level of BUMDes development are also the main issues that are always questioned by BUMDes operational executives. The presence of laws and regulations related to BUMDes that currently exists has not been able to provide clear legal politics in determining the level of BUMDes development that has minimal potential for disharmony. The presence of the BUMDes Bill is an effort to overcome this issue.

The BUMDes Bill, of course, will be able to provide qualified legal politics in determining the level of BUMDes development that is in accordance with the spirit of kinship and mutual cooperation as well as village deliberation as the foundation in the operation of BUMDes. Then, through the establishment of the BUMDes Bill, it can become a lex specialis that prevent the operation of BUMDes and its business units from overlapping or disharmony with other laws and regulations. Through the BUMDes Bill, it is still possible to direct the development of BUMDes through its business units that are legal entities. However, the mechanism for establishing these legal entity business units shall be simplified to produce a hybrid model of a legal entity business unit and to accommodate the fundamental principles of BUMDes operation as mandated by the Village Law.

Then, the settlement of implementation problems such as reporting procedures, accounting systems and bankruptcy can also be a strategic material content because based on the reality to date, the existing laws and regulations related to BUMDes have not been able to provide clear arrangement which is in line with the principles of BUMDes operation as mandated by the Village Law. In fact, the existing laws and regulations have created serious disharmony regarding the imposition of BUMDes losses as explained in the previous paragraphs.

Then, concern about disharmony or overlap between the Village-Owned Enterprise Law and the Village Law will not necessarily occur. Further regulation of a material content of the Law in another Law. Even the law which is lex specialis is not a new thing in Indonesia. For example, Law Number 26 Year 2007 concerning Spatial Planning is strengthened by Law Number 27 Year 2007 concerning Management of Coastal Areas and Small Islands as amended by Law Number 1 Year 2014.

Moreover, the constitutional mandate of Article 33 of the 1945 Constitution determines that the implementation of the economy as a joint business which is based on the principle of kinship is further regulated in the Law. Therefore, a juridical basis can be formulated regarding the Village-Owned Enterprise Law as follows "whereas in order to organize Village-Owned Enterprise as an economic activity based on the principle of kinship, it is necessary to regulate further in the Law".

\section{CONCLUSION}

In the current management of BUMDes, there is a disorientation in the implementation of BUMDes regulations and policies, including: First, the incompatibility of Village regulations with other laws and regulations in the field of village government affairs which is not accommodated by one ministry. Second, the low level of community initiative in driving the village economy, the unclear position of BUMDes as a social and commercial institution and policies that have not directed the professionalism of BUMDes.

\section{SUGGESTION}

Reinforce legal politics that are qualified in determining the level of development of BUMDes in accordance with the spirit of kinship and mutual cooperation as well as village deliberation as the foundation in the operation of BUMDes. The drafting of the BUMDes Bill can become a lex specialis that avoids the operation of BUMDes and its business units from overlapping or disharmony with other laws and regulations. The acceleration of village welfare will be accommodated in the 
BUMDes Bill, but it can still direct the development of BUMDes through its business units that are legal entities. The solution in accelerating village welfare through BUMDes is to provide BUMDes flexibility in the form of a legal entity as a bridge to be able to increase capital in the investment sector. Develop clear sanctions for village government officials and BUMDes managers if they commit fraud.

\section{ACKNOWLEDGMENT}

The authors would like to thank the Management of the De Jure Legal Research Journal who has been willing to process and publish this simple research. We also want to thank the academicians of the Universitas Pembangunan Nasional Veteran Jakarta and the Muhammadiyah University of North Sumatera who supported the two authors to complete this research.

\section{BIBLIOGRAPHY}

Abib, Agus Saiful, Endah Pujiastuti, and Tri Mulyani. "Konsep Penanaman Modal Sebagai Upaya Mestimulasi Peningkatan Perekonomian Indonesia.” Hukum dan Masyarakat Madani 7, no. 1 (2017): 19-39.

Agunggunanto, Edy Yusuf, Fitrie Arianti, Edi Wibowo Kushartono, and Darwanto. "PENGEMBANGAN DESA MANDIRI MELALUI PENGELOLAAN BADAN USAHA MILIK DESA ( BUMDes ) Fitrie Arianti Universitas Diponegoro Semarang.” Jurnal Dinamika Ekonomi dan Bisnis 13, no. 1 (2016): 67-81.

Anggraeni, Maria Rosa Ratna Sri. "Peranan Badan Usaha Milik Desa (Bumdes) Pada Kesejahteraan Masyarakat Pedesaan Studi Pada Bumdes Di Gunung Kidul, Yogyakarta.” Modus 28, no. 2 (2016): 155.

Bachtiar, Palmira, Asep Kurniawan, Gema Satria Mayang Sedyadi, Rendy Diningrat, Ruhmaniyati, and Ulfah Alifia. Laporan Studi Kasus Undang-Undang Desa: Menelusuri Manfaat Belanja Desa. Jakarta, 2019.

Badan Pusat Statistik. Statistik Infrasruktur Indonesia 2020 (Hasil Pemutakhiran Data Perkembangan Desa 2020). Jakarta: Badan Pengkajian MPR RI, 2020.
- Statistik Infrastruktur Indonesia 2019 Hasil Pemutakhiran Data Perkembangan Desa 2019. Jakarta: Badan Pusat Statistik, 2019.

. Village Potential Statistics of Indonesia 2018. Jakarta: Badan Pusat Statistik, 2018.

Basalamah, Muhammad Ridwan. "Optimisation of Management of BUMDes: The Case in East Java Province" 4, no. 2 (2021): 14-22.

Berdesa. "Informasi Lengkap Tentang BUMDes Yang Harus Anda Ketahui.” Berdesa.Com.

Departemen Pendidikan Nasional Pusat Kajian Dinamika Sistem Pembangunan (PKDSP) Fakultas Ekonomi. Buku Panduan Pendirian Dan Pengelolaan Badan Usaha Milik Desa. Malang: Universitas Brawijaya, 2007.

Direktur Pelaksanaan Anggaran - Ditjen Perbendaharaan. "Pedoman Penyaluran Dana Desa Ta 2021.” Jakarta: Kementerian Keuangan, 2021.

Dirkareshza, Rianda. "Aspek Usaha Bersama Berdasarkan Asas Kekeluargaan Dalam Pembatalan UU No. 17 Tahun 2012 Terkait Putusan Mahkamah Konstitusi No. 28/PUUXI/2013.” Universitas Sumatera Utara, 2016.

Dispmd, Admin. "Memahami Dan Mengerti : Badan Usaha Milik Desa (BUMDes)." Dispmd.Bulelengkab.Go.Id.

Hadi, Sutrisno. Metodologi Riserch 1. Yogyakarta: Gajah Mada, 1980.

Hendrik, Okta. "Peran Kepala Desa Dalam Penyelenggaraan Pembangunan Desa Tanjung Keranjang Kecamatan Malinau Kota Kabupaten Malinau.” eJournal Ilmu Pemerintahan 2, no. 2 (2013): 459-469.

Humas KEMENKO PMK. “2020, Dana Desa Fokus Pada Pemberdayaan Masayarakat Dan Pengembangan Potensi Ekonomi Desa." Www.Kemenkopmk.Go.Id.

Junaidi, Muhammad Adib. "Peran Badan Usaha Milik Desa (BUMDes) Dalam Penguatan Ekonomi Di Desa Kedung Turi Kecamatan Taman Kabupaten Sidoarjo.” UNAIR Article 1, no. 1 (2018): 10.

Kania, Ikeu, Grisna Anggadwita, and Dini Turipanam Alamanda. "A New Approach to Stimulate Rural Entrepreneurship through 
Village-Owned Enterprises in Indonesia.” Journal of Enterprising Communities: People and Places in the Global Economy 15, no. 3 (January 2021): 432-450.

Laurensius Arliman S. "Penanaman Modal Asing Di Sumatera Barat Tentang Penanaman Modal.” Supremasi Jurnal Hukum 1, no. 1 (2018): 8-22.

Marbun, Beni Haryanto, Marlon Sihombing, and R. Hamdani Harahap. "Peranan Dana Desa Dalam Pengembangan Indeks Desa Membangun Di Kecamatan Sibolangit Kabupaten Deli Serdang Provinsi Sumatera Utara.” Perspektif 9, no. 2 (2020): 438-446.

Ngadisah, N, and A Alma'arif. "Peran Dan Fungsi Bumdes Dalam Pembangunan Perdesaan (Studi Pada Desa Bleberan Kecamatan Playen Diy)." Jurnal Manajemen Pembangunan 2, no. 1 (2019).

Priadi Asmanto, Siti Nurfitriah Farah Dewi, Imelda Leiwakabessy, Mohammad Maulana, and Sutikno. "Pendayagunaan Badan Usaha Milik Desa Dalam Pemulihan Ekonomi Pascawabah Covid-19.” Sekretariat Tim Nasional Percepatan Penanggulangan Kemiskinan. Jakarta: Sekretariat Tim Nasional Percepatan Penanggulangan Kemiskinan, 2020.

Pusat Perancangan dan Kajian Hukum (Pusperjakum) DPD RI. "Ini Faktor PendukungDanPenghambatBerkembangnya BUMDes." Https://Www.Desapedia.Id/.

Putra,Anom Surya. Badan Usaha MilikDesa Spirit UsahaKolektifDesa.Jakarta:EMENTERIAN DESA, PEMBANGUNAN DAERAH TERTINGGAL, DAN TRANSMIGRASI REPUBLIK INDONESIA, 2015.

Sadiawati, Diani et.al. Kajian Reformasi Regulasi Di Indonesia: Pokok Permasalahan Dan Strategi Penanganannya. Kementerian PPN/ Bappenas. Jakarta: Yayasan Studi Hukum dan Kebijakan Indonesia (YSHK), 2019.

Sagita, Garnies Lellyana. "Peran Badan Usaha Milik Desa (BUMDes) Dalam Meningkatkan Kesejahteraan Masyarakat Desa Berdasarkan UU No. 6 Tahun 2014 Tentang Desa (Studi Kasus BUMDes Tirta Mandiri Klaten).”
Universitas Muhammadiyah Surakarta.

Universitas Muhammadiyah Surakarta, 2017.

Se, Hyronimus, and Lambertus Langga. "Peranan BUMdes Dalam Mendukung Perekonomian Dan Meningkatkan Kesejateraan Masyarakat Desa Watusipi Kecamatan Ende Kabupaten Ende.” Resona Jurnal Ilmiah Pengabdian Masyarakat 5, no. 1 (2021): 75-86.

Siagian, Ade Onny. "Analisis Pengembangan Badan Usaha Milik Desa (Bumdes) Harapan Oesena Di Desa Oesena Kecamatan Amarasi Kabupaten Kupang." Jurnal Riset Entrepreneurship 4, no. 1 (2021): 33.

Sidik, Fajar. "Implementasi Kebijakan Badan Usaha Milik Desa (Bumdes): Unit Usaha, Pendapatan Dan Inefisiensi.” Jurnal Ekologi Birokrasi 5, no. 3 (2017): 36-46.

Soemitro, Ronny Hanitijo. Metode Penelitian Hukum. Jakarta: Ghalia Indonesia, 1985.

Suparji. Pedoman Tata Kelola BUMDes. Jakarta: UAI Press, 2019.

Surono, Agus. "Peranan Hukum Dalam Pengelolaan Sumber Daya Alam Skala Desa Oleh Badan Usaha Milik Desa (BUMDes) Dalam Meningkatkan Kesejahteraan Masyarakat Desa.” Jurnal Rechts Vinding: Media Pembinaan Hukum Nasional 6, no. 3 (2017): 459.

Widayanti, Riris Eka, and Renny Oktafia. "Strategi Pemasaran Berbasis Online Pada Produk Badan Usaha Milik Desa (Bumdes) 'Sukses Bersama' Desa Sugihwaras Kabupaten Sidoarjo.” Jurnal Tabarru': Islamic Banking and Finance 4, no. 1 (2021): 242-252.

Wijaya, Endra, and Mochamad Firmansyah Roni. "Praktik Pengelolaan Keuangan Desa Dan Faktor-Faktor Yang Memengaruhinya." Jurnal Ilmiah Kebijakan Hukum 13, no. 2 (2019): 165.

Wiwoho, Jamal. "Peran Lembaga Keuangan Bank Dan Lembaga Keuangan Bukan Bank Dalam Memberikan Distribusi Keadilan Bagi Masyarakat.” Masalah-Masalah Hukum 43, no. 1 (2014): 87-97.

Wijaya, E., Mochamad Firmansyah Roni, "Praktik Pengelolaan Keuangan Desa Dan Faktor- 
Faktor Yang Memengaruhinya,” Jurnal Ilmiah Kebijakan Hukum 13, no. 2 (2019): 165.

Budijanto, Oki Wahju. "Peningkatan Akses Bantuan Hukum Kepada Masyarakat Miskin.” Jurnal Penelitian Hukum De Jure 16, no. 4 (2017): 463-475. https://ejournal. balitbangham.go.id/index.php/dejure/article/ viewFile/193/56.

Darmawan, Oksimana. "Implementasi Norma Standard Di Rumah Detensi Jakarta Dalam Upaya Pencegahan Konflik Antar Deteni.” Jurnal Ilmiah Kebijakan Hukum 10, no. 1 (2016): 71-86.

Gayo, Ahyar Ari. "Perlindungan Hukum Hak Atas Tanah Adat (Studi Kasus Di Provinsi Aceh Khususnya Kabupaten Bener Meriah) (Legal Protection For Title Over Customary Land (Case Study In The Province Of Aceh In Particular, The Regency Of Bener Meriah)).” De Jure jurnal penelitian hukum 18, no. 3 (2018): 15.

Jawardi, Jawardi. "STRATEGI PENGEMBANGAN BUDAYA HUKUM (Strategy of Law Culture Development)." Jurnal Penelitian Hukum De Jure 16, no. 1 (2016): 77.

Muhaimin, Muhaimin. "Rekonstruksi Penggunaan Dana Desa Untuk Mewujudkan Kesejahteraan Masyarakat Desa.” Jurnal Penelitian Hukum De Jure 20, no. 4 (2020): 557.

Nugroho, Oksimana Darmawan; Okky Chahyo. "IMPLEMENTASI KEBIJAKAN PENGUSULAN DESA/KELURAHAN BINAAN MENJADI DESA/KELURAHAN SADAR HUKUM (Policy Implementation Proposing Construction Village to Become Village Aware of Law).” Jurnal Penelitian Hukum De Jure 20, no. 2 (2020).

Surono, Agus. "Peranan Hukum Dalam Pengelolaan Sumber Daya Alam Skala Desa Oleh Badan Usaha Milik Desa (BUMDes) Dalam Meningkatkan Kesejahteraan Masyarakat Desa.” Jurnal Rechts Vinding: Media Pembinaan Hukum Nasional 6, no. 3 (2017): 459.
Yasin, Muhammad, Ahmad Rofi, Fachurrahman, Bejo Untung, Maya Rostanty, Setyo Dwiherwanto, Iskandar Saharudin, and Fitria Muslih. Anotasi Undang-Undang No.6 Tahun 2014 Tentang Desa. Jakarta: Pusat Telaah dan Informasi Regional (PATTIRO), 2014.

Yuliani, Nur Laili, Wibi Darmawan, Isti Arvakni, Syaifana Diana Marantika, Ni Made Rizkie Devi, and Kurniawati. "Pengembangan Dan Pemberdayaan BUMDes Di Dusun Bebengan, Salaman, Magelang Guna Meningkatkan Perekonomian Masyarakat.” Community Empowerment 6, no. 3 (2021): 343-346. 
HALAMAN KOSONG 